\title{
Rubricoccus marinus gen. nov., sp. nov., of the family 'Rhodothermaceae', isolated from seawater
}

Correspondence

Sanghwa Park

psh214@hotmail.com

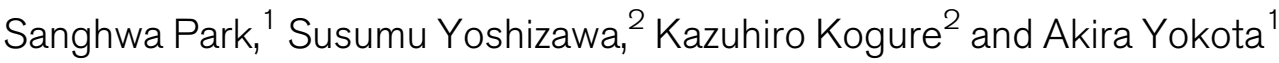

\author{
${ }^{1}$ Institute of Molecular and Cellular Biosciences, The University of Tokyo, 1-1-1 Yayoi, Bunkyo-Ku, \\ Tokyo 113-0032, Japan \\ ${ }^{2}$ Atmosphere and Ocean Research Institute, The University of Tokyo, 5-1-5 Kashiwanoha, Kashiwa, \\ Chiba 277-8564, Japan
}

The family 'Rhodothermaceae' of the class 'Cytophagia' in phylum Bacteroidetes (Ludwig et al., 2008) includes three genera at the time of writing: Rhodothermus (Alfredsson et al., 1988), Salinibacter (Antón et al., 2002) and the recently proposed genus Salisaeta (Vaisman \& Oren, 2009). Members of these genera have been isolated from extreme environments and exhibit extreme thermophilic or halophilic characteristics: Rhodothermus marinus was isolated from submarine hot springs in Iceland, Salinibacter ruber was isolated from hypersaline crystallizer ponds in Spain and Salisaeta longa was isolated from the Dead Sea (Israel/ Jordan). At present, the name 'Rhodothermaceae' has not been validly described.

An aerobic, red-pigmented bacterium was isolated from seawater samples obtained from the western North Pacific Ocean $\left(30^{\circ} 40^{\prime} \mathrm{N} 138^{\circ} 00^{\prime} \mathrm{E}\right.$; depth $\left.50 \mathrm{~m}\right)$ during voyage KT-09-11 of RV Tansei Maru on 2-6 July 2009 (Ocean Research Institute, The University of Tokyo and Japan Agency for Marine-Earth Science and Technology). Samples $(200 \mu \mathrm{l})$ were inoculated onto medium G (containing $\mathrm{l}^{-1} 80 \%$ aged seawater: $0.5 \mathrm{~g}$ peptone, $0.1 \mathrm{~g}$ yeast extract, $5 \mathrm{~g}$ Gelrite) and incubated at $15{ }^{\circ} \mathrm{C}$ for 30 days. The isolated strain was routinely cultivated and maintained on half-strength marine agar 2216 (1/2 MA; containing $\mathrm{l}^{-1}$ : $4.4 \mathrm{~g} \mathrm{MgCl}_{2}$, $2.5 \mathrm{~g}$ peptone, $1.62 \mathrm{~g} \mathrm{Na}_{2} \mathrm{SO}_{3}, 0.9 \mathrm{~g} \mathrm{CaCl}_{2}$,

The GenBank/EMBL/DDBJ accession number for the 16S rRNA gene sequence of strain $\mathrm{SG}-29^{\top}$ is $\mathrm{AB} 545808$.
0.5 g yeast extract, $0.27 \mathrm{~g} \mathrm{KCl}, 0.8 \mathrm{~g} \mathrm{NaHCO}_{3}, 0.5 \mathrm{~g}$ ferric citrate, $0.04 \mathrm{~g} \mathrm{KBr}, 0.015 \mathrm{~g} \mathrm{SrCl}_{2}, 0.01 \mathrm{~g} \mathrm{H}_{3} \mathrm{BO}_{3}, 4 \mathrm{mg}$ $\mathrm{Na}_{2} \mathrm{HPO}_{4}, 2 \mathrm{mg} \mathrm{Na} \mathrm{SiO}_{3}, 1.2 \mathrm{mg} \mathrm{NaF}, 0.8 \mathrm{mg} \mathrm{NH} \mathrm{NO}_{3}$, 15 g agar; Difco) with $2 \% \mathrm{NaCl}$ at $20{ }^{\circ} \mathrm{C}$.

Growth at $5,10,15,20,25,30,37$ and $45^{\circ} \mathrm{C}$, at pH 5-10 and with $0-15 \% \mathrm{NaCl}$ was determined on $1 / 2 \mathrm{MA}$ containing $2 \% \mathrm{NaCl}$ unless otherwise specified. Gramstaining was performed as described by Murray et al. (1994). Cell morphology and motility were observed using light microscopy (BX60; Olympus) and transmission electron microscopy (JEOL 1011 TEM). Growth under anaerobic conditions was determined after incubation for 4 weeks in an AnaeroPack (Mitsubishi Gas Chemical Co). Catalase activity was determined by bubble formation in a $3 \% \mathrm{H}_{2} \mathrm{O}_{2}$ solution. Oxidase activity was determined using cytochrome oxidase test paper (Nissui Pharmaceutical). API $20 \mathrm{E}$, API $20 \mathrm{NE}$, API $50 \mathrm{CH}$ and API ZYM strips (bioMérieux) were used to determine physiological and biochemical characteristics. The suspension medium for the API tests contained $2 \%(\mathrm{w} / \mathrm{v}) \mathrm{NaCl}$. Results of API 20 E, API $20 \mathrm{NE}$ and API $50 \mathrm{CH}$ were recorded after 5 days and those of API ZYM were recorded after 2 days at $20{ }^{\circ} \mathrm{C}$. Determination of the respiratory quinone was carried out as described by Xie \& Yokota (2003). For analysis of fatty acid methyl esters, cells were prepared for 3 weeks at $20{ }^{\circ} \mathrm{C}$ and fatty acids were extracted and prepared according to the standard protocols provided by 
the MIDI/Hewlett Packard Microbial Identification system (Sasser, 1990).

Genomic DNA was prepared according to the method of Marmur (1961) and the DNA base composition was determined using the HPLC method of Mesbah et al. (1989). A fragment of approximately $1450 \mathrm{bp}$ of the $16 \mathrm{~S}$ rRNA gene was amplified from extracted DNA using universal bacterial primers (27F and 1492R; Lane, 1991; Weisburg et al., 1991). To ascertain the phylogenetic position of strain SG-29 $9^{\mathrm{T}}$, the $16 \mathrm{~S}$ rRNA gene sequence was compared with sequences obtained from GenBank (National Center for Biotechnology Information; http://www.ncbi.nlm.nih.gov) using FASTA. Multiple alignments of sequences were performed using CLUSTAL X version 1.83 (Thompson et al., 1997) and gaps and ambiguous bases were omitted for sequence comparison. Aligned sequences were analysed using MEGA version 4 (Tamura et al., 2007). Evolutionary distances were calculated using distance options according to the Kimura two-parameter model (Kimura, 1983). Clustering with the neighbour-joining (Saitou \& Nei, 1987) and maximumlikelihood (Felsenstein, 1981) methods was performed using PAUP version 4 (Swofford, 2002). Bootstrap values (Felsenstein, 1985) were calculated from 1000 replications. Similarities were calculated using the same software values.

Cells of strain SG-29 ${ }^{\mathrm{T}}$ after 3 weeks at $20{ }^{\circ} \mathrm{C}$ were coccoid and amorphous, reddish pigmented and approximately $0.3-$ $0.5 \mu \mathrm{m}$ in diameter. Spores were not observed (Fig. 1). A reddish pigment was extracted from cells by using acetone after freeze drying and was analysed by spectrophotometry (Du-530; Beckman). The pigment showed a UV-visible spectrum with absorption maxima at $474 \mathrm{~nm}$ and $446 \mathrm{~nm}$. No growth was observed under anaerobic conditions; growth occurred only under aerobic conditions. The temperature range for growth was $5-37{ }^{\circ} \mathrm{C}$. Optimum conditions for growth were $20-30{ }^{\circ} \mathrm{C}$ and $\mathrm{pH} 5-9$. The isolate required sodium ions for growth and grew with $1-5 \% \mathrm{NaCl}$. The cultural, physiological and biochemical characteristics of strain SG-29 ${ }^{\mathrm{T}}$ were compared with Salisaeta longa S4-4 ${ }^{\mathrm{T}}$, Salinibacter ruber $\mathrm{M} 31^{\mathrm{T}}$ and Rhodothermus marinus DSM $4252^{\mathrm{T}}$ (Table 1). The major cellular fatty acids of strain

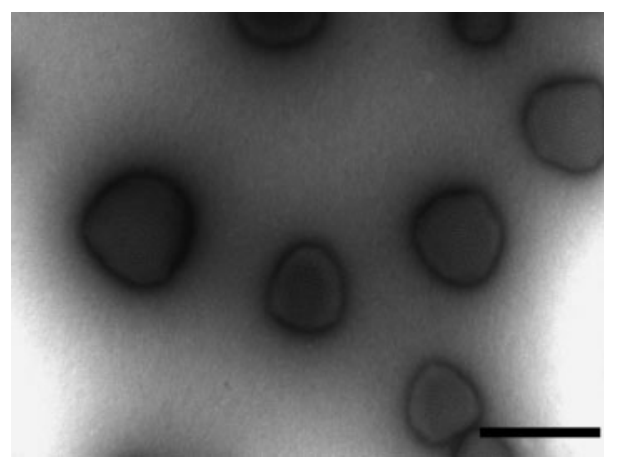

Fig. 1. Transmission electron micrograph of cells of strain $\mathrm{SA}-29^{\top}$, showing coccoid and amorphous morphology. Bar, $500 \mathrm{~nm}$.
Table 1. Differential characteristics of strain $S G-29^{\top}$ and related members of the phylum Bacteroidetes

Strains: 1, Rubricoccus marinus sp. nov. SG-29 ${ }^{\mathrm{T}}$; 2, Salisaeta longa S4-4 ${ }^{\mathrm{T}}$ (data from Vaisman \& Oren, 2009); 3, Salinibacter ruber M $31^{\mathrm{T}}$ (Antón et al., 2002); 4, Rhodothermus marinus DSM $4252^{\mathrm{T}}$ (Sako et al., 1996). All strains are catalase-positive.

\begin{tabular}{|lcccc|}
\hline Characteristic & $\mathbf{1}$ & $\mathbf{2}$ & $\mathbf{3}$ & $\mathbf{4}$ \\
\hline Pigment & Reddish & Red & Red & Reddish \\
Cell dimensions $(\mu \mathrm{m})$ & $0.3-0.5$ & $15-30$ & $0.4-2.6$ & $2-2.5$ \\
Temperature for growth $\left({ }^{\circ} \mathrm{C}\right)$ & & & & \\
$\quad$ & $5-37$ & $37-46$ & $32-47$ & $54-77$ \\
$\quad$ Range & $20-30$ & $37-46$ & $37-47$ & 65 \\
Optimum & $1-5$ & $5-20$ & $15-30$ & $2-6$ \\
NaCl for growth $(\%, \mathrm{w} / \mathrm{v})$ & 68.85 & 62.9 & 66.5 & 64.4 \\
DNA G+C content $(\mathrm{mol} \%)$ & - & + & + & + \\
Oxidase & & & & \\
\hline
\end{tabular}

SG-29 ${ }^{\mathrm{T}}$ were iso- $\mathrm{C}_{17: 1} \omega 9 c(21.9 \%), \mathrm{C}_{17: 1} \omega 8 c(16.9 \%)$, iso$\mathrm{C}_{17: 0}(14.5 \%)$ and $\mathrm{C}_{16: 0}(7.6 \%)$, which distinguished the isolate from the three genera of the phylum Bacteroidetes (Table 2).

An almost-complete 16S rRNA gene sequence for strain SG-29 ${ }^{\mathrm{T}}$ was determined and showed that the isolate belonged to the phylum Bacteroidetes. Analysis using 1278 bases showed that all of the type strains of species with validly described names exhibited $<87 \%$ 16S rRNA gene sequence similarity with strain SG-29 ${ }^{\mathrm{T}}$ : $86.1 \%$ with Rhodothermus obamensis JCM 9785 ${ }^{\mathrm{T}}$, 85.9\% with Rhodothermus marinus DSM $4252^{\mathrm{T}}$ (the type strain of the type species of genus Rhodothermus), $85.4 \%$ with Salisaeta longa S4 $44^{\mathrm{T}}, 85.3 \%$ with Rhodothermus profundi PRI $2902^{\mathrm{T}}$ and $84.8 \%$ with Salinibacter ruber $\mathrm{M} 31^{\mathrm{T}}$. Phylogenetic trees obtained using the neighbour-joining method (Fig. 2) and maximum-likelihood method (data not shown) revealed clear affiliations between strain SG-29 $9^{\mathrm{T}}$ and the cluster

Table 2. Major cellular fatty acid composition of strain SG-29 ${ }^{\top}$ and related members of the phylum Bacteroidetes

Strains: 1, Rubricoccus marinus sp. nov. SG-29 ${ }^{\mathrm{T}}$; 2, Salisaeta longa S4-4 ${ }^{\mathrm{T}}$ (data from Vaisman \& Oren, 2009); 3, Salinibacter ruber M $31^{\mathrm{T}}$ (Bardavid et al., 2007); 4, Rhodothermus marinus DSM $4252^{\mathrm{T}}$ (Marteinsson et al., 2010). -, Not detected; ND, no data available.

\begin{tabular}{|lcccc|}
\hline Fatty acid (\%) & $\mathbf{1}$ & $\mathbf{2}$ & $\mathbf{3}$ & $\mathbf{4}$ \\
\hline iso- $_{15: 0}$ & 3.9 & 8.5 & 25 & 6 \\
anteiso- $_{15: 0}$ & 0.2 & 3.8 & 3.9 & 12.3 \\
$\mathrm{C}_{16: 0}$ & 7.6 & $\mathrm{ND}$ & 9.8 & 4.1 \\
iso- $_{16: 0}$ & 2.2 & $26-30$ & - & 27.8 \\
$\mathrm{C}_{16: 1} \omega 9 c$ & 0.5 & $35-38$ & 29 & $\mathrm{ND}$ \\
iso- $_{17: 0}$ & 14.5 & $\mathrm{ND}$ & 0.9 & 20.7 \\
anteiso-C $_{17: 0}$ & 0.4 & $\mathrm{ND}$ & 1.1 & 13.9 \\
$\mathrm{C}_{17: 1} \omega 8 c$ & 16.9 & $\mathrm{ND}$ & $\mathrm{ND}$ & $\mathrm{ND}$ \\
iso- $_{17: 1} \omega 9 c$ & 21.9 & $\mathrm{ND}$ & $\mathrm{ND}$ & $\mathrm{ND}$ \\
$\mathrm{C}_{18: 1} \omega 11 c$ & - & $\mathrm{ND}$ & 24.4 & $\mathrm{ND}$ \\
\hline
\end{tabular}




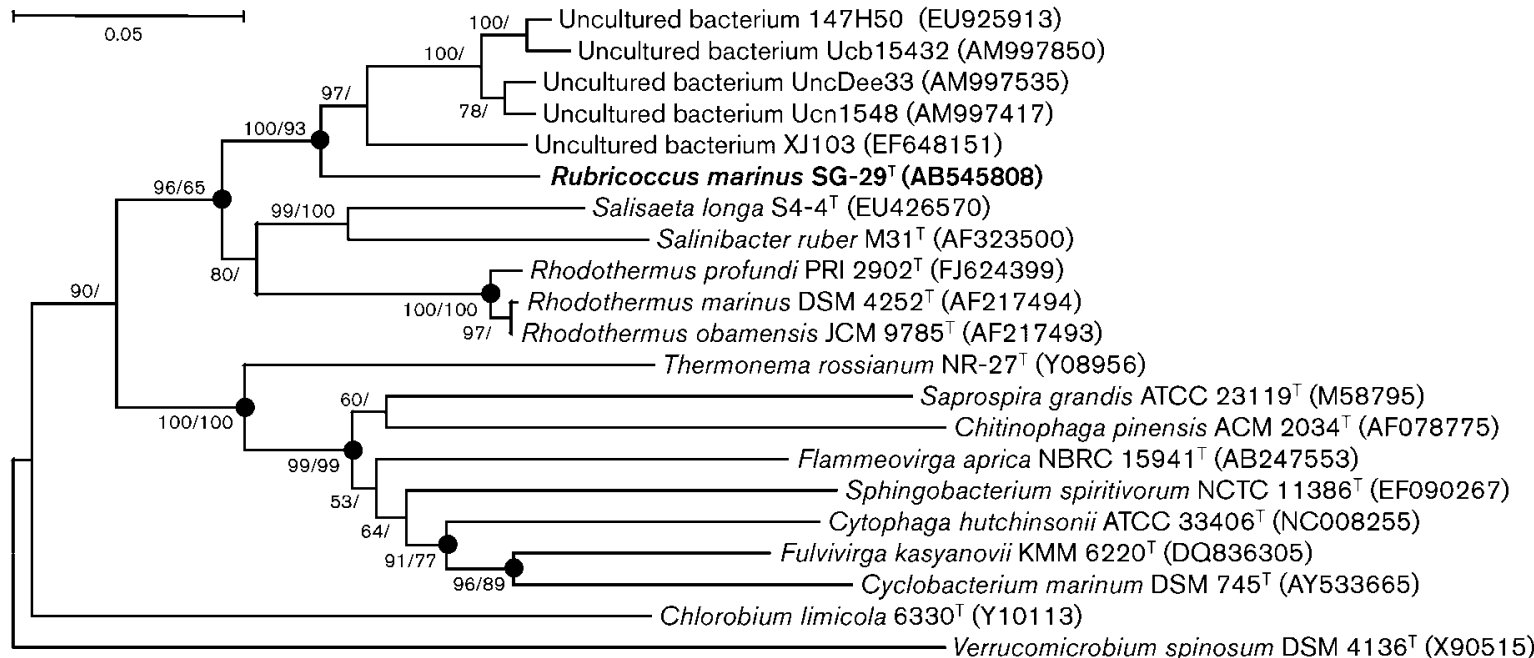

Fig. 2. Neighbour-joining phylogenetic tree based on $16 \mathrm{~S}$ rRNA gene sequences, showing the position of strain SG-29 among related members of the phylum Bacteroidetes. Bootstrap values ( $>50 \%)$ based on 1000 replications are shown at branch nodes (neighbour-joining/maximum-likelihood);,$-<50 \%$. Filled circles indicate nodes recovered with $>50 \%$ bootstrap support in the maximum-likelihood tree. Chlorobium limicola $6330^{\top}$ and Verrucomicrobium spinosum DSM $4136^{\top}$ were used as an outgroup. Bar, 0.05 substitutions per nucleotide position.

containing Salisaeta longa S4-4 ${ }^{\mathrm{T}}$, Salinibacter ruber $\mathrm{M} 31^{\mathrm{T}}$ and Rhodothermus marinus DSM $4252^{\mathrm{T}}$, and strain SG-29 was placed on a separate branch within this cluster.

Phenotypic, chemotaxonomic and genotypic differences between strain SG-29 $9^{\mathrm{T}}$ and members of related genera showed that strain $\mathrm{SG}-29^{\mathrm{T}}$ is sufficiently different to be assigned to a novel genus in the family 'Rhodothermaceae'. The name Rubricoccus marinus gen. nov., sp. nov. is proposed.

\section{Description of Rubricoccus gen. nov.}

Rubricoccus (Ru.bri.coc'cus. L. adj. ruber reddish; N.L. n. coccus from Gr. masc. n. kokkos a berry, unit; N.L. masc. n. Rubricoccus reddish coccus).

Cells are reddish, coccoid and amorphous, non-gliding, Gram-stain-negative and obligately aerobic. The major respiratory quinone is MK-7. The $\mathrm{G}+\mathrm{C}$ content of the genomic DNA is $68.9 \mathrm{~mol} \%$. The predominant cellular fatty acids $(>10 \%)$ are iso- $\mathrm{C}_{17: 1} \omega 9 c, \mathrm{C}_{17: 1} \omega 8 c$ and iso$\mathrm{C}_{17: 0}$. The type species is Rubricoccus marinus.

\section{Description of Rubricoccus marinus sp. nov.}

Rubricoccus marinus (ma.ri'nus. L. masc. adj. marinus of the sea, marine).

Exhibits the following properties in addition to those given in the genus description. Cells are $0.3-0.5 \mu \mathrm{m}$ in diameter. Grows at $5-37{ }^{\circ} \mathrm{C}$ (optimum $20-30{ }^{\circ} \mathrm{C}$ ), but not at $45{ }^{\circ} \mathrm{C}$, at $\mathrm{pH} 5-9$ and with $1-5 \%(\mathrm{w} / \mathrm{v}) \mathrm{NaCl}$. Catalase-positive and oxidase-negative. Positive for esterase (C4), esterase lipase (C8), lipase (C14), leucine arylamidase, valine arylamidase, cystine arylamidase, trypsin, $\alpha$-chymotrypsin, acid phosphatase and naphthol-AS-BI-phosphohydrolase, but negative for alkaline phosphatase, $N$-acetyl- $\beta$-glucosaminidase, $\alpha$-and $\beta$-galactosidases, $\alpha$ - and $\beta$-glucosidases, $\beta$-glucuronidase, $\alpha$-mannosidase and $\alpha$-fucosidase. Produces acetoin, reduces nitrate to nitrogen and weakly hydrolyses gelatin. Acid is produced from aesculin, 2-ketogluconate, turanose and arabinose. The major cellular fatty acids are iso- $\mathrm{C}_{17: 1} \omega 9 c, \mathrm{C}_{17: 1} \omega 8 c$, iso- $\mathrm{C}_{17: 0}$ and $\mathrm{C}_{16: 0}$. The DNA $\mathrm{G}+\mathrm{C}$ content of the type strain is $68.9 \mathrm{~mol} \%$.

The type strain, SG $-29^{\mathrm{T}} \quad\left(=\mathrm{NBRC} 107124^{\mathrm{T}}=\right.$ KCTC $\left.23197^{\mathrm{T}}\right)$, was isolated from the western North Pacific Ocean near Japan.

\section{Acknowledgements}

We are grateful to the officers and crew of R/V Tansei Maru [Atmosphere and Ocean Research Institute, The University of Tokyo and Japan Agency for Marine-Earth Science and Technology (JAMSTEC)] for their assistance and support in sample collection.

\section{References}

Alfredsson, G. A., Kristjansson, J. K., Hjorleifsdottir, S. \& Stetter, K. O. (1988). Rhodothermus marinus gen. nov., sp. nov., a thermophilic, halophilic bacterium from submarine hot springs in Iceland. J Gen Microbiol 134, 299-306.

Antón, J., Oren, A., Benlloch, S., Rodríguez-Valera, F., Amann, R. \& Rosselló-Mora, R. (2002). Salinibacter ruber gen. nov., sp. nov., a novel, extremely halophilic member of the Bacteria from saltern crystallizer ponds. Int J Syst Evol Microbiol 52, 485-491.

Bardavid, R. E., lonescu, D., Oren, A., Rainey, F. A., Hollen, B. J., Bagaley, D. R., Small, A. M. \& McKay, C. (2007). Selective enrichment, 
isolation and molecular detection of Salinibacter and related extremely halophilic Bacteria from hypersaline environments. Hydrobiologia 576, 3-13.

Felsenstein, J. (1981). Evolutionary trees from DNA sequences: a maximum likelihood approach. J Mol Evol 17, 368-376.

Felsenstein, J. (1985). Confidence limits on phylogenies: an approach using the bootstrap. Evolution 39, 783-791.

Kimura, M. (1983). The Neutral Theory of Molecular Evolution. Cambridge: Cambridge University Press.

Lane, D. J. (1991). 16S/23S rRNA sequencing. In Nucleic Acid Techniques in Bacterial Systematics, pp. 115-147. Edited by E. Stackebrandt \& M. Goodfellow. Chichester: Wiley.

Ludwig, W., Euzéby, J. \& Whitman, W. B. (2008). Draft taxonomic outline of the Bacteroidetes, Planctomycetes, Chlamydiae, Spirochaetes, Fibrobacteres, Fusobacteria, Acidobacteria, Verrucomicrobia, Dictyoglomi, and Gemmatimonadetes. http://www.bergeys.org/outlines/Bergeys_Vol_ 4_Outline.pdf

Marmur, J. (1961). A procedure for the isolation of deoxyribonucleic acid from microorganisms. J Mol Biol 3, 208-218.

Marteinsson, V. T., Bjornsdottir, S. H., Bienvenu, N., Jakob, K., Kristjansson, J. K. \& Birrien, J.-L. (2010). Rhodothermus profundi sp. nov., a thermophilic bacterium isolated from a deep-sea hydrothermal vent in the Pacific Ocean. Int J Syst Evol Microbiol 60, 2729-2734.

Mesbah, M., Premachandran, U. \& Whitman, W. B. (1989). Precise measurement of the $\mathrm{G}+\mathrm{C}$ content of deoxyribonucleic acid by highperformance liquid chromatography. Int J Syst Bacteriol 39, 159-167.

Murray, R. G. E., Doetsch, R. N. \& Robinow, F. (1994). Determinative and cytological light microscopy. In Methods for General and
Molecular Bacteriology, pp. 21-41. Edited by P. Gerhardt, R. G. E. Murray, W. A. Wood \& N. R. Krieg. Washington, DC: American Society for Microbiology.

Saitou, N. \& Nei, M. (1987). The neighbor-joining method: a new method for reconstructing phylogenetic trees. Mol Biol Evol 4, 406425.

Sako, Y., Takai, K., Ishida, Y., Uchida, A. \& Katayama, Y. (1996). Rhodothermus obamensis sp. nov., a modern lineage of extremely thermophilic marine bacteria. Int J Syst Bacteriol 46, 1099-1104.

Sasser, M. (1990). Identification of bacteria by gas chromatography of cellular fatty acids, MIDI Technical Note 101. Newark, DE: MIDI Inc.

Swofford, D. L. (2002). PAUP*: Phylogenetic analysis using parsimony (and other methods), version 4. Sunderland, MA: Sinauer Associates.

Tamura, K., Dudley, J., Nei, M. \& Kumar, S. (2007). MEGA4: molecular evolutionary genetics analysis (MEGA) software version 4.0. Mol Biol Evol 24, 1596-1599.

Thompson, J. D., Gibson, T. J., Plewniak, F., Jeanmougin, F. \& Higgins, D. G. (1997). The CLUSTAL_X windows interface: flexible strategies for multiple sequence alignment aided by quality analysis tools. Nucleic Acids Res 25, 4876-4882.

Vaisman, N. \& Oren, A. (2009). Salisaeta longa gen. nov., sp. nov., a red, halophilic member of the Bacteroidetes. Int J Syst Evol Microbiol 59, 2571-2574.

Weisburg, W. G., Barns, S. M., Pelletier, D. A. \& Lane, D. J. (1991). $16 \mathrm{~S}$ ribosomal DNA amplification for phylogenetic study. J Bacteriol 173, 697-703.

Xie, C. H. \& Yokota, A. (2003). Phylogenetic analyses of Lampropedia hyalina based on the 16S rRNA gene sequence. J Gen Appl Microbiol 49, 345-349. 